\title{
Investing for the Environment? The Limits of the UN Principles of Responsible Investment
}

\author{
Taylor R. Gray \\ University of Oxford, School of Geography and the Environment, South Parks Rd., Oxford OX1 3QY, UK \\ Contact: taylor.gray@ouce.ox.ac.uk
}

\begin{abstract}
International governance is often complicated by collective action problems. This is particularly true in the setting of international environmental governance in which attempts to establish effective international regimes are marred by countless private and public actors with distinct agendas, significant issue uncertainty, and a diversity of non-synchronized initiatives. In light of these difficulties, efforts are underway to embed an international environmental regime within the already developed and, arguably, better understood international regime of global finance. This developing ideology involves financial market participants no longer treating environmental consequences of economic growth as externalities but rather internalizing them as financial risks within their decision-making processes, and is often referred to as responsible investment. The United Nations Principles of Responsible Investment (UN PRI) has played a leading role in these efforts and has benefited significantly from uncritical optimism in doing so. However, an analysis of the UN PRI demonstrates that the organization's lack of transparency, accountability and enforcement actually serve as obstacles to the mainstream adoption of responsible investment practices. The UN PRI, after early successes in legitimizing the responsible investment ideology, appears to be acting as a shroud of legitimacy for traditional 'non-responsible' investment practices. Although the UN PRI may have gained autonomous authority and have diverted from its original goals, the responsible investment ideology retains the promise of being an effective regime to address contemporary environmental change in a world driven by global finance, yet more support from both private and public actors, and corresponding oversight of all actors, is required.
\end{abstract}

Keywords: International Governance, Environmental Regimes, UN PRI, Legitimacy

Acknowledgements: The author would like to thank Gordon Clark, Janelle Knox-Hayes, and Adam Dixon for their comments on earlier drafts. Support for this research has been provided by the Clarendon Fund. The original version of this paper was presented at the oikos Foundation/ UN Principles of Responsible Investment Young Scholars Finance Academy 2009. All errors, omissions, and opinions are the sole responsibility of the author. 


\section{Introduction}

Contemporary trends in globalization are generating ever increasing demands for effective international governance. International governance regimes are typically issue-specific and operate along a spectrum ranging from soft to hard law; soft law approaches are more commonly employed given the costs of nation-state sovereignty and collective-action problems inherent in establishing international hard law (Abbott and Snidal 2000). Although soft law has the benefit of being dynamic in the face of uncertainty this same dynamism also leads it to be increasingly influenced by a multiplicity of actors, both public and private (Falkner 2003). The rise in influence of private non-state organizations, including NGOs, corporations, and influential individuals, who draw legitimacy from civil society and not from nationstate institutions (Hall and Biersteker 2002), has been described as one of the most significant developments in international governance of late (Doh and Guay 2006). In certain governance settings these non-state actors have the potential to cultivate sufficient legitimacy and rule-making authority so as to displace public actors (Rosenau 1997).

International environmental governance is just one such setting where the demand for international governance as well as the number of involved actors seems to be growing exponentially. International environmental regimes remain little understood (e.g. Wettestad 2001; Young 2002), much less so than international economic regimes (e.g. Kindleberger 1988; Kerwer 2005). Standards are often turned to as effective soft law mechanisms in international governance (Abbott and Snidal 2001) and no other policy setting has witnessed an equal growth in international standards than the setting of global finance (Kerwer 2005). As such, there is growing interest in embedding international environmental regimes within the better understood, and arguably more stable, international economic regimes of global finance. In essence, such an environmental regime would involve financial market participants no longer treating environmental consequences of economic growth as externalities but rather internalizing them as financial risks within their decision-making processes.

The internationalization of nation-states (Glassman 1999) and the turn to financial markets as a repository of national and personal savings have created a global financial market dominated by universal owner institutional investors. These investors own entire cross-sections of national economies and are less exposed to single corporate or market segment developments and more so to systemic national and international economic performance (Hawley and Williams 2000). Public pension funds represent the most important constituency of universal owners given the depth of their capital pools, their position as fiduciaries to broad ranging social cohorts, and their long-term investment horizon (Ryan and Schneider 2002; Clark and Hebb 2005). To place the market dominance of pension funds in perspective one should note that, as of December $31^{\text {st }}, 2006$, global pension fund assets under management totalled \$26.0 trillion USD (IFSL 2008), equivalent to approximately 39.4 percent of world GDP in 2006 (based on purchase price parity)(CIA 2009).

A growing recognition of their market dominance and systemic exposure is leading certain institutional investors to incorporate traditionally non-financial metrics in their investment processes, such as the California Public Employees' Retirement System's (CaIPERS) concern with corporate governance (Hebb 2006) or the incorporation of an ethical investment mandate within the Norwegian Government Pension Fund-Global (Gjessing and Syse 2007). This investment ideology, commonly referred to as responsible investment, encourages institutional investors to address corporate social and environmental performance not out of altruistic moral concern but more so out of concern for long-term investment value. If successful, the responsible investment ideology would lead to long-term financial value predicated on economic growth with low environmental impact. 
As a developing ideology, responsible investment has been influenced by both private and public actors, but none have had as large a role as the United Nations Principles of Responsible Investment (UN PRI). The UN PRI is an international non-state organization which aggregates institutional investors and their supporting service providers in order to define and implement responsible investment practices. As an early mover in this developing policy setting the UN PRI has the potential to benefit from the opportunity to create actors, define responsibilities, and construct a new social understanding (Finnemore 1993). In short, the UN PRI is attempting to develop a new international standard, one which has remained little discussed to date but nonetheless has significant international political economic consequences.

In this article I maintain the position that the developing responsible investment regime holds significant promise to effectively address global environmental problems within the setting of contemporary capitalism and I seek to critically address the role of the UN PRI in this developing international regime. I discuss how the UN PRI has been instrumental in legitimizing the responsible investment ideology and thereby laying the foundation for the development of an international standard. I also demonstrate, however, that the UN PRI's continued lack of transparency, enforcement and accountability is in fact serving as an obstacle to the mainstream adoption and implementation of responsible investment practices. The UN PRI's structure and culture lead it to be perceived more so as interested in retaining social legitimacy as an autonomous international organization and less so as an agent of change. Although the UN PRI has benefited greatly from uncritical optimism to date, its degree of perceived legitimacy, from which it gains rule-making authority in an international political economy, is in doubt; the consequences of which are significant for the development of an international responsible investment regime.

Following, section two develops the importance of institutional investors in both international financial and environmental regimes. Section three discusses the growth of non-state organizations in international governance with particular attention paid to the importance of retaining organizational legitimacy. Section four provides an overview and analysis of both the form and function of the UN PRI. This analysis includes discussions from the perspective of the UN PRI as an autonomous organization as well as from the perspectives of individual signatory institutional investors and concerned external audiences. Section five concludes the article by discussing the implications of the UN PRI for the growth and adoption of the responsible investment ideology and practices as well as the role of private and public actors in generating an international regime capable to addressing contemporary environmental problems.

\section{Environmental Governance and Institutional Investors}

The case of international environmental governance is particularly chaotic as ecosystems seldom conform to geopolitical boundaries (Bailey 1983) and certain environmental constituents such as water, air, and the atmosphere are truly global commons (Nordhaus 1994). Global environmental change presents two significant challenges to nation-states (developed in Biermann and Dingwerth 2004). First, demand for action places additional strain on a national government's limited resources and ability to provide for its citizens' welfare, thereby generating a demand for non-state actors to assume some degree of responsibility (Charnovitz 1996). Second, the inter-jurisdictional reality of environmental change requires increased cooperation between nation-states thereby threatening traditional concepts of state sovereignty. The multiplicity of actors within environmental governance creates a necessity for 
international cooperation yet this same cooperation is often plagued by collective action problems (Young 1990).

Although certain environmental problems have been effectively addressed by international regimes, such as the Montreal Protocol concerning CFCs (e.g. Murdoch and Sandler 1997), a coherent and broadscale international environmental regime is lacking. Contemporary global environmental change is often problematized under the rubric of climate change. Regardless of the uncertainty inherent to a limited understanding of such a complex system, it is seldom questioned that climate change is exacerbated by anthropogenic influences and presents significant social, environmental, and economic risks to humanity (IPCC 2007; Stern 2007). The international response to this global problem has been beset by a significant multitude, diversity, and non-synchronized proliferation of policies and actions (Pattberg and Stripple 2008). Witness the UN-sponsored Kyoto protocol, often heralded as the flagship international response to climate change, which is currently marred in political bargaining, problems of inaction and free-riding, and a multiplicity of actors which renders collective agreement near impossible.

In light of these difficulties, and based on the understanding that the majority of environmental problems arise as consequences of being treated as an externality of economic growth, there is increasing interest in establishing international environmental regimes within the better understood, and arguably more stable, international economic regimes of global finance. Following, much effort is focused on the roles of institutional investors within global finance given their significant market authority (e.g. Davis and Steil 2001).

During the latter portion of the twentieth century, as capitalist nation-states increasingly turned to financial markets for economic growth, a number of institutional investors, such as pension funds, banks, insurance funds, mutual funds and endowments, were receiving and investing ever increasing pools of capital. Of greatest concern was the growth of pension funds which were the beneficiaries of mandated contributions (Clark 2000) and which have been labelled the 'building blocks of the world's capital markets' (Sparkes 2002, p.4). Following Glassman's (1999) understanding of the internationalization of nation-states, it is precisely these institutional investors which are the driving force of international financial flows.

With such large pools of capital and a necessity to diversify, following Markowitz's (1952) modern portfolio theory based on analysis of risks and returns of individual equities within wider portfolios (Campbell and Viceira 2002), institutional investors have come to be universal owners by which they own entire cross-sections of economies (Hawley and Williams 2000; 2005). Due to their large market presence and exposure, universal owners are effectively denied the ability of exit when faced with dissatisfactory equity performance (Coffee 1991). As such, institutional investors are increasingly concerned with fundamental firm value and associated risks (Clark and Hebb 2005) and are increasingly prone to pro-actively address issues of concern (Hebb 2008).

Universal owners, given their international risk exposure, require significant quantities of information and financial intermediary services in order to successfully implement their investment strategies (Clark and Wójcik 2007). Representing such a lucrative market segment, the financial services industry, including investment managers and professional service providers, has effectively been oriented towards defining and meeting the needs of institutional investors. Combined, these asset owners and service providers constitute institutional investor value chains which are unparalleled market forces in global finance (Hebb and Wójcik 2005). 
These value chains have been correlated with significant financial and managerial alterations within individual corporations (e.g. Wahal 1996; Strickland et al. 1996; Del Guercio and Hawkins 1999; Gillan and Starks 2000; Nelson 2006) as well as with political economic consequences in various emerging markets (Hebb and Wójcik 2005), and established markets such as Japan (Jacoby 2007) and continental Europe (Bauer et al. 2008). Furthermore, the historic episode of investor divestiture from apartheid South Africa in the 1980s clearly demonstrates the political economic consequences of coordinated institutional investor action (Sparkes 2002).

Given their concern with the distribution of risks, institutional investors are increasingly encouraged to focus on corporate performance metrics which have traditionally been considered external to mainstream finance (Mercer 2009). These corporate performance metrics are commonly aggregated under the headings of environmental, social, and governance (ESG) metrics. These risk metrics have been correlated with corporate financial performance and should be of concern to all fiduciaries [for environmental risks see Klassen and McLaughlin 1996; Shameek and Cohen 2001; Derwall et al. 2005, for social risks, see the Orlitzky et al. 2003 meta-analysis, for governance risks see Gompers et al. 2003; Bebchuk et al. 2009].The inclusion of ESG metrics in investment decision-making is understood to reduce long-term risks across all asset classes (Center for Corporate Citizenship 2007). Furthermore, the incorporation of ESG metrics in investment decision-making is expected to raise global standards of corporate performance.

Given their structure as fiduciaries, these institutional investors, and pension funds in particular, are accountable to their beneficiaries, which in many cases include entire cross-sections of national societies or even international diasporas of peoples. These funds are required to invest with their beneficiaries' best interests in mind and, as the inclusion of ESG metrics is correlated with long-term value, incorporating ESG metrics in investment strategies does not contravene fiduciary duty in either common or civil law jurisdictions (Freshfields 2005). Furthermore, the speed at which information travels combined with the monopolistic access large institutional investors have to this information (Kacperczyk and Seru 2007) creates a situation in which these investors can be highly adaptive to a situation in determining the optimal allocation of their resources.

Institutional investors are an important constituency of international finance and the developing responsible investment ideology has the potential to be the foundation of an international environmental regime embedded within. The responsible investment ideology will require significant action on behalf of other private and public actors to ensure its development. Research on pension fund governance, the pillars of the institutional investor community, demonstrates that these funds follow convention rather than be innovative as they are highly path-dependent and in many cases may not be up-to date with current financial market and corporate governance structures and/or cultures (Clark 1998). Furthermore, the governance of these funds is highly politicized as directors are often nominated to represent government, unions, and employers and not necessarily for their financial acumen (Impavido 2002).

As such, additional actors are required to facilitate and encourage the adoption of responsible investment ideologies and practices. Certain national political regimes have come to recognize the importance of institutional investors as corporate monitors in conjunction with regulatory agencies. The UK Corporations Act has recently been reformed to require additional corporate disclosure on issues of ESG performance which may be considered material to corporate performance and public pension funds are required to report to what extent they account for ESG metrics in their investment decision-making. These regulatory actions are expected to provide for a more informed and efficient market, one in which private actors hold considerable power. 


\section{Growth of Non-State Organizations}

Although the debate concerning the relevance of nation-states in an increasingly integrated global economy will undoubtedly persist (e.g. Ohmae 1995 vs. Yeung 1998), the balance of these perspectives lies within Glassman's description of the internationalization of the state 'in which the state apparatus becomes increasingly oriented towards facilitating capital accumulation for the most internationalized investors, regardless of their nationality' (Glassman 1999, p.673).

This process of internationalization has not only created a balance of power between regulatory and market forces but has also created space for non-state organizations to manoeuvre as they seek to influence decision-making processes. Non-state organizations have been active in governance since 1775 and have traveled a cyclical path determined mostly by the needs of governments and the capabilities of the organizations, somewhat along the lines of 'political demand and supply' (Charnovitz 1996, p.269). Non-state organizations have become increasingly prominent since the 1990s with the advent of economic globalization and the awareness of ecological interdependence. Such organizations have participated in international governance by influencing the behaviour of individuals, businesses, and society at large (Wapner 1995).

The rise of non-state market-driven (NSMD) environmental governance systems is a clear example of the rise of a non-state organization to influence corporate decision-making in an internationalized space (Bernstein and Cashore 2007). NSMD environmental governance systems grew in prominence throughout the 1990s as state-level policy makers were confronted with increasing social pressure to address environmental protection while at the same time operating with reduced resources to effectively do so (Cashore and Vertinsky 2000). The privatization of environmental governance via the emergence of NSMD governance systems, such as the Forest Stewardship Council, emerged as a supposed compromise solution (Fletcher and Hansen 1999; Steelman and Rivera 2006). These systems aim to introduce environmental and social considerations into corporate decision-making on par with financial considerations in an attempt to force domestic and international standards upward (Meidinger 1997).

Non-state organizations derive their rule-making authority not from nation-state sovereignty but from civil society and market forces (Cashore 2002; Cashore et al. 2004). Such authority is dependent on the organization's degree of social legitimacy which is 'a generalized perception or assumption that the actions of an entity are desirable, proper, or appropriate within some socially constructed system of norms, values, beliefs and definitions' (Suchman 1995, p.574). External audiences can award such legitimacy based on moral, pragmatic, and/or cognitive considerations (Suchman 1995; Bernstein and Cashore 2007).

In the 1970s and 1980s globalization was lead by forces operating within consumer markets and the internationalization of financial flows followed predominantly as a supporting mechanism (Aliber 1984). As such, the case of NSMD environmental governance systems has been played out in the globalized consumer markets. With the increasing importance of financial markets since the 1980s, however, flows of finance have been recognized as the predominant force of market globalization (Jordan and Majnoni 2002) and the debate has shifted to the role of nation-states within this new setting (e.g. Stulz 2005).

Non-state organizations have witnessed the growth in power and authority of this internationalized financial setting. The forces at play in consumer markets aiming to incorporate social and environmental metrics into corporate decision-making have resurged in financial markets to promote the incorporation of similar values in investment decision-making. These non-state organizations aim to harness the power of shareholders in an attempt to influence corporate behaviour irrespective of nation-state jurisdictions. 
The United Nations Principles of Responsible Investment (UN PRI) has been at the forefront of this developing policy setting. The UN PRI is an investor initiative in partnership with the United Nations Environment Program-Finance Initiative and the United Nations Global Compact. The UN PRI consists of a set of six voluntary and aspirational principles with the objective of integrating ESG concerns into mainstream investment decision-making. Responding to an invitation from the UN Secretary-General in 2005, representatives from 20 institutional investors along with supporting staff and UN representatives formed the Investor Group which was tasked with developing the principles. The UN PRI has since grown to be the leading international responsible investment framework with 362 signatories which control over \$15 trillion USD. As of May $1^{\text {st }}, 2008$, signatories included 133 asset owners, 152 investment managers, and 77 professional service partners.

As a fledging organization in a nascent political economic setting, the UN PRI has been tasked with two principal objectives. The first is to define and legitimize the responsible investment ideology and the second is to subsequently render the ideology actionable and oversee its implementation in mainstream financial markets. If the UN PRI can establish and retain sufficient legitimacy, it has the opportunity to become a leading actor with governance authority in an internationalized political economy far superior to that of many nation-states. Most international organizations benefit from a high degree of uncritical optimism and ultimately stray from their stated efficiency goals and wield power autonomously (Barnett and Finnemore 1999); since its inception in 2005 the UN PRI has remained a beneficiary of such uncritical optimism.

\section{The UN PRI}

\subsection{Legitimizing Responsible Investment}

Although increasingly used by academics and practitioners the term responsible investment is seldom explicitly defined. The difficulty resides primarily in defining which investment behaviours are responsible and by extension which are irresponsible. The contention is further exacerbated by the UN PRI's desire to define a globally accepted ideology. Given that responsibility is a subjective value embedded in regulative, normative, and cultural-cognitive social institutions (Scott 2001; Sorsa 2008), in combination with the diversity of social institutional forms throughout the world, a globally accepted definition of 'responsible' is, arguably, impossible to achieve.

In light of this, the UN PRI has not explicitly defined responsible investment but rather provided six principles which allow for the construction of a community of practice (Wenger 1999; Amin and Cohendet 1999) which will in turn, through negotiations, compromise, and actions/inactions, lead to an understanding of responsible investment. The implicitness of responsible investment allows for more actors to participate without being constrained by an explicit definition with which they may not fully agree. The Investor Group formed the original community of practice and remains at the core of the ever expanding community of practice. To date, this community of practice has been able to define responsible investment as a combination of engaged shareownership and the inclusion of ESG concerns in investment decision-making. Engaged shareownership and ESG metric-based investment strategies have not, however, been explicitly defined and remain open to idiosyncratic interpretations by all signatories.

The UN PRI community of practice is composed of its signatories which have been categorized as asset owners, investment managers, and professional service providers. The signatories come from all regions of the world including North America, Latin America, Europe, Asia, Oceania, Africa, and the Middle East. 
The majority of signatories are mainstream pension funds, insurance funds, and investment managers, followed by a minority of traditional socially responsible investment funds (UN PRI 2008). Although not explicitly identified in UN PRI material, the determining characteristic identifying traditional socially responsible investment funds appears to be their respective profit motivations. These funds are willing to sacrifice profit, if necessary, in order to reflect their ethical values in their investment decisionmaking. Accordingly, the UN PRI promotes the perspective that responsible investment is fundamental to strong long-term value and does not promote a normative ethical position on investment decisionmaking.

The inclusion of ESG metrics is a milestone in the development of a more explicit definition of responsible investment. Prior to this term, similar investment ideologies were referred to as socially responsible investment (SRI) or social, ethical, and environmental (SEE) metrics (Sparkes 1995; Hummels and Timmel 2004). At issue with these terms is the connotation that ethical or social responsibility implied a secondary prioritization of financial returns. Such strategies have remained marginal to the mainstream finance industry in large part because most institutional investors perceived such strategies as a breach of fiduciary duty.

Although SRI and SEE were to remain marginalized, the respective industries have managed to attach a sufficient degree of legitimacy to the associated strategies in order to remain viable. Traditional SRI investment initiatives throughout the twentieth century, based on strict moral values, necessarily attributed a moral legitimacy to the movement (Sparkes 1995). Numerous SRI-related indices, such as the FTSE4Good indices, the Dow Jones Sustainability indices, and the Jantzi Social indices, have since become a minor yet stable presence in financial markets (Haigh and Hazelton 2004).

Similar investment strategies were further legitimized as a few universal owners began successfully relying on metrics which were traditionally not considered to be financially-relevant in their investment decision-making. For example the California Public Employees' Retirement System's (CalPERS) reliance on corporate governance metrics (Hebb 2006, 2008) attributed a degree of pragmatic legitimacy to this process. The pragmatic legitimacy was further supported by studies which documented a positive correlation between corporate financial performance and traditionally non-financial metrics (Orlitzky et al. 2003; Derwall et al. 2005).

Ultimately, however, it has been the UN PRI community of practice which has established sufficient legitimacy for the mainstream use of such metrics in investment decision-making. Whereas the terms SRI and SEE implied a subordination of financial returns in favour of ethical considerations, the term ESG has been defined and promoted as an investment strategy which is directly related to long-term financial value. The ESG term and supporting performance research has rendered it more difficult for investors to disregard ESG metrics under the premise that to do so would contravene fiduciary duty. Research has demonstrated that the inclusion of ESG metrics in investment decision-making processes does not contravene fiduciary duty in either common or civil law jurisdictions and that reticence towards the incorporation of ESG metrics is more likely due to a lack of information and products as well as a penchant for conventional investment practices (Freshfields 2005).

The UN PRI community of practice successfully coined the term ESG which is void of any connotations of financial subordination and sufficiently implicit to entice a significant number of market actors to become signatories. With such a large array of signatories including some of the world's largest and most financially successful universal owners, the responsible investment ideology is quickly gaining sufficient cognitive legitimacy to enter the domain of mainstream finance. 


\subsection{Implementing the UN PRI}

Legitimacy for the responsible investment ideology does not necessarily equate to mainstream legitimacy for responsible investment practices. Having accomplished the legitimation of the ideology the UN PRI is now tasked with its broad-scale implementation.

The UN PRI has expanded its organizational framework to include a reporting and assessment tool. This assessment tool is an annual survey signatories are invited to complete which highlights their performance in implementing the six principles. All signatories which have been involved in the UN PRI for more than one year are required to complete the reporting and assessment exercise whereas other signatories are invited to do so voluntarily. Although completion of the exercise is, for some, a requirement, signatories are not required to disclose the outcome of their reports.

The PRI Report on Progress 2008 is the second annual report arising from the reporting and assessment process. As of $31^{\text {st }}$ December 2007, 116 asset owners and 116 investment managers were signatories to the UN PRI, and all 232 of these members were invited to participate in the reporting process. The process resulted in a 67 percent response rate with 78 asset owners and 78 investment managers choosing to participate. The reporting process was based on signatory self-assessment in relation to predominantly qualitative indices (i.e. large extent, medium extent, small extent, etc...). It is important to note that some signatories have expressed a concern that other reporting signatories were overestimating their degree of implementation and execution (UN PRI 2008).

The report provides summary results on numerous facets of the organization's, and its signatories', operations. Of direct interest to this discussion are the responses concerning 1) the developing responsible investment relationship between the signatories and their investees, 2) signatory collaboration on responsible investment strategies, and (3) signatory success in internalizing and implementing responsible investment strategies.

Signatory/investee relations are instrumental in generating a supply and demand curve for ESG information which is critical for developing responsible investment strategies. Twenty-three percent of asset owning respondents have 'asked investee companies to produce standardized reporting on their RI/ESG issue policies, practices or performance' (Q51) to a large extent whereas 26 percent have not done so at all. Nine percent of asset owning respondents 'have provided feedback to investee companies on their reporting on RI/ESG issues' (Q53) to a large extent whereas 35 percent have not done so at all. Furthermore 24 percent of asset owning respondents are 'revisiting relationships with service providers in light of RI/ESG issue-related capabilities' (Q67) whereas 59 percent are not.

Effective signatory collaboration on responsible investment strategies is at the heart of the UN PRI community of practice's continued development. The PRI Engagement Clearinghouse is an on-line members' forum in which signatories can outline their initiatives in an effort to seek support and refine their strategies. Twenty-nine percent of asset owning respondents have used the clearinghouse whereas 38 percent have not; and 3 percent of asset owning respondents reported having posted to the clearinghouse (Q72). Although a minority of asset owning respondents have made use of the clearinghouse, 66 percent report that their use of the clearinghouse did result in action or collaboration (Q73).

Perhaps most interesting, however, is the data concerning the use of responsible investment performance metrics. These performance metrics are required in order for institutional investors to gauge the success of their initiatives. Only 13 percent of asset owning respondents 'have sought to determine what impact their RI/ESG issue-related approach has had on the performance of their 
portfolio' (Q91) to a large extent whereas 38 percent have not done so at all. These results drop to 5 percent and 36 percent respectively when addressing the 'extent to which respondents have sought to determine what impact their RI/ESG issue-related efforts, requests, and guidance have had on the consideration of RI/ESG issues by their external investment managers' (Q92).

A clear trend in UN PRI asset owner implementation is visible within the PRI Report on Progress 2008. The UN PRI has been successful in attracting numerous asset owners to become signatories, yet not all asset owning members act on the principles in the same manner. It would appear that a significant minority of asset owning members have fully internalized the responsible investment ideology of the UN $\mathrm{PRI}$ and rendered the strategies actionable. These members could be said to represent the core group of the UN PRI signatory base. The remaining signatories, which could be labelled the peripheral group, have as of yet to act on the ideology in a meaningful manner. The peripheral group, for all intents and purposes, appears to be free-riding on the efforts of the core group. In this case, free-riders are benefitting from the UN PRI in terms of access to: (1) competitive information regarding responsible investment strategies; (2) monopolistic information regarding forthcoming institutional investor actions; and (3) a degree of social legitimacy provided by the veneer of an UN-associated organization.

\subsection{Motivational Drivers of Signatories}

It is important that we understand why institutional investors become signatories to the UN PRI thereby making a public commitment to responsible investment when few appear willing to act on the commitment. Although all institutional investor signatories are uniformly classified as asset owners they are in fact a heterogeneous group given each fund's unique economic, political, and social antecedents (Ryan and Schneider 2002). In broad terms, institutional investor motivations can be categorized as addressing legitimacy, competitive, and ethical concerns (Aguilera et al. 2006).

The motivational drivers of the core group, those which have internalized the spirit of responsible investment, are more easily generalized. These signatories can be understood to be motivated primarily by ethical concerns. In this sense, ethical concerns are not necessarily related to altruistic behaviour but refer primarily to the funds' sense of duty and loyalty to their principals. For many such institutional investors, engaged ownership and ESG metric incorporation are strategic components in ensuring longterm value, which ultimately reflects the fund's fiduciary duty to its beneficiaries (e.g. Hebb 2006 on CalPERS' approach to engaged ownership). These funds would likely recognize the UN PRI as an opportunity to refine their investment strategies in a collaborative manner thereby reducing agency costs.

The motivational drivers of the remaining asset owners, the peripheral group which have not internalized the responsible investment ideology, can be analyzed first by categorizing the funds as public or private. Public institutional investors are managed by a board of trustees and receive their investment capital by means of mandated and/or voluntary contributions. The beneficiaries of public institutional investors, when dissatisfied with the board of trustees can become engaged by means of certain governance channels however usually cannot relocate any investment capital to another institutional investor. Private institutional investors, on the other hand, are represented by management teams which actively compete for investment capital. The beneficiaries of private institutional investors are free to remove and relocate their investment capital as they see fit.

Inherent to their organizational structure, public institutional investors are not concerned with competitive motivations and are driven primarily by a need for social legitimacy. The concern over social legitimacy is similar to the corporate social license to operate (Valor 2005) and has become a necessity as public institutional investors have come to be recognized as significant drivers of the global economy. 
It is possible that certain public fund trustees may be motivated by altruistic ethical concerns however it would be difficult to act on such motivations if a majority of the fund trustees and a majority of the beneficiaries were not motivated by similar concerns. This is particularly the case if acting on the ethical concerns would sacrifice potential investment returns.

Private institutional investors, on the other hand, do not benefit from mandated contributions and must attract and retain investment capital. As such, these funds are primarily motivated by competitive concerns and each will develop its own competitive strategy. Successful competitive strategies will have two principal components. The first is that fund performance will out-perform respective benchmark indices. The second is that the fund will have distinguishing characteristics which differentiate it from other funds which also out-perform respective benchmark indices. The responsible investment ideology is one such potential distinguishing characteristic. Private funds which participate in traditional SRI practices are understood to be motivated not from competitive concerns but more so from ethical concerns, however traditional SRI funds represent only a minority of the UN PRI signatory base.

Institutional investors will adopt responsible investment strategies to a degree sufficient to fulfill the motivational force inherent to their organization. Although scholars and practitioners may draft an idealized assemblage of strategies it is unlikely that institutional investors would internalize this ideal and render it operational. Most public institutional investors, motivated by a search for social legitimacy, will incrementally adopt strategies to the point at which they attain sufficient legitimacy. As the responsible investment discourse is immature, social legitimacy is perhaps attainable by simply forming a research group to investigate the possibility of creating such investment strategies. Similar forces are at play in private institutional investors who will shape their responsible investment strategies to attract a particular customer segment. As customer interests change these private funds will seek to adapt their strategies to keep pace; reflexively, they may also adopt certain strategies in an attempt to influence customer interests. Accordingly, the peripheral group of UN PRI signatories should not be expected to further internalize the responsible investment ideology/strategies until their desired legitimacy is jeopardized.

\subsection{UN PRI Legitimacy Concerns}

As a non-state organization, the UN PRI cannot resort to apparatuses of sovereign authority to bolster its rule-making powers. Instead, the UN PRI's legitimacy rests on how external audiences perceive the organization based on moral, pragmatic, and cognitive concerns (Suchman 1995). The difficulty in analyzing the UN PRI legitimacy is in the diversity of concerned external audiences. The UN PRI is an international organization which is an agent of its signatory principals (primarily institutional investors) which in turn are the agents of their principals (fund beneficiaries). Further complicating matters is the reality that although the UN PRI is not beholden to any particular nation-state its fundamental signatories, the public pension funds, are in fact beholden to particular nation-states. Accordingly, external audiences may be interested in the UN PRI due to its potential political, financial, and/or public consequences.

The UN PRI has managed to remain uncritically addressed to date. As such it is difficult to identify discreet external audiences and analyze their concerns at this time. In what follows, I will address the political, financial, and public consequences of the continued development of the UN PRI. This discussion should serve to identify areas of concern which are expected to be fundamentally critical in future perceptions of UN PRI legitimacy.

The political consequences of the UN PRI are driven by the fact that contemporary capitalist nationstates are inter-dependent on corporations (Shonfield 1965; Offe 1975) which are, in turn, dependent 
on flows of finance. The UN PRI is effectively attempting to alter capital accumulation and distribution patterns throughout the world thereby influencing the nation-state/corporation relationship. In promoting responsible investment strategies the UN PRI is attempting to establish a new international standard, and as in the case of most international standards, as they become influential they fall prey to questions of democratic accountability (Kerwer 2005).

The UN PRI is not beholden to any particular nation-state. The responsible investment ideology and practices established by the UN PRI community of practice are effectively based on a compromise of international norms and values. This international compromise may not be amenable to all nation-states as it is achieved by international market participants, some of which are politically charged and some not, with no degree of ensured representative democracy.

The signatory base of the UN PRI, although global, is not uniformly distributed. European participants represent 41 percent of the signatory base and control \$9.7 trillion USD. North American and Oceanic participants each represent 19 percent of the signatory base although North American signatories control \$2.3 trillion USD and Oceanic signatories control \$570 billion USD. Asian participants in turn represent 8 percent of signatories, less than half of Oceanic participants, but control \$1.46 trillion USD which represents double the sum of Oceanic capital. African, Latin American, and Middle Eastern participants each represent less than 8 percent of the signatory base and each control less than $\$ 500$ billion USD. Further complicating matters is that not all signatories are equally active in constructing, supporting, and promoting the UN PRI and the associated responsible investment ideology, as witnessed above by the inaction of the peripheral group of signatories. Without greater transparency, it is impossible to determine the power structure of the UN PRI community of practice.

Yet the UN PRI attempts to speak with one voice with the illusion that this voice is supported by $\$ 15$ trillion USD of globally invested capital. The representativeness of that voice is questionable. The board of directors is composed of 11 representatives of asset owning members and 2 representatives of the UN organizations. The qualification of asset owning board members, how they are appointed, and their degree of oversight of the UN PRI secretariat are critical characteristics of the organization's governance yet remain unclear. Although both North American and Oceanic signatories account for 19 percent of the signatory base and Asian signatories account for 8 percent, there are currently three North American board members, only one Oceanic board member, and only one Asian board member. The lack of transparency and accountability within the board creates a situation in which the voice of the UN PRI may not be that of its members but more so that of its executive directors.

Audiences should also be interested in the UN PRI's financial consequences for two reasons. First, the UN PRI community if practice acts as a catalyst for the creation of a new mainstream financial services industry. As institutional investor interest in corporate governance grew throughout the 1990s (Hebb 2008) an entire corporate governance industry, replete with analysts, rating firms, and consultants grew to satisfy their informational and managerial demands (Rose 2007); a similar industry is fledging in the nascent ESG space, as documented by the ever increasing number of professional service providers which become signatories to the UN PRI. Second, UN PRI signatories control sufficient capital, over $\$ 15$ trillion USD, to require other actors to adjust their market strategies if they successfully implement the novel responsible investment strategies. Combined, these two developments have the potential to significantly alter the finance industry's competitive landscape.

At a finer level of analysis, individual beneficiaries of signatory institutional investors are less concerned with the UN PRI as an autonomous organization and more so concerned with individual signatory fund performance. As the majority of asset owning signatories are not from the traditional SRI industry, the 
associated beneficiaries can be considered to be unwilling to sacrifice potential returns in exchange for reflecting moral values in investment decision-making. These active beneficiaries are liable to voice their concern to, or withdraw their capital from, any signatory which internalizes the UN PRI strategies and performs below respective benchmarks. In this occasion, the UN PRI pragmatic legitimacy will be jeopardized.

Audiences concerned with the public consequences of the UN PRI are perhaps less fundamental in the organization's attempts to establish rule-making authority. Members of the public audience can be individuals or other organizations but all remain truly external to the UN PRI and cannot make recourse to any financial or political channels of direct governance. As such, and following from Clarkson's (1995) stakeholder theory, these individuals and organizations are secondary to the UN PRI as their behaviour could potentially have significant consequences for the organization yet their support is not necessary for its continuation. The public concern over the UN PRI is likely to grow from the public's perception of the organization as a global citizen (Carter 2001) in which it is an efficient mechanism to promote increased global economic responsibility. The force of this public perception is expressed, as discussed above, as the social landscape within which large public institutional investors seek their legitimacy.

This attempt to identify the principal concerns of the UN PRI external audiences is not definitive as the organization remains in its infancy and is only now beginning to draw wider attention. Further complicating the analysis of the UN PRI's dependence on external audiences for legitimacy is the fact that the international organization is a program of the United Nations. The United Nations is widely considered to be the preeminent international organization with unparalleled legitimacy (Tharoor 2003). Although difficult to quantify, the UN PRI has undeniably benefited from this associated degree of legitimacy.

\subsection{UN PRI-Agent of change?}

The UN PRI has aggregated a remarkable community of some of the most powerful market forces in today's internationalized political economy - the institutional investor value chains-and has the potential to coordinate the development of a novel international environmental regime embedded within the architecture of global finance. The UN PRI is not the first non-state organization to attempt to harness the market authority of institutional investors but it is the first to do so in such a wide-reaching and holistic manner.

Other organizations such as CERES, the International Interfaith Investment Group (3iG), the Carbon Disclosure Project (CDP), and the Extractives Industries Transparency Initiative (EITI) are also premised on the aggregation of institutional investor market authority, yet none match the breadth and depth of the UN PRI. Both CERES and 3iG have been successful in gaining sufficient legitimacy to remain operable but remain marginal due to restrictions on their signatory base (only USA- or faith-based institutional investors respectively) and single-issue objectives (environmental sustainability). Both the CDP and the EITI have been successful in establishing a global presence yet remain marginal within mainstream financial markets as they are less concerned with altering institutional behaviour and more concerned with harnessing institutional investor support in order to leverage it as a statement of interest in their attempt to entice corporations to either improve their carbon-related disclosure or to entice extractivebased corporations and local governments to disclose the terms of their operating contracts, respectively.

As such, the UN PRI is unique in that its signatory base is international and focuses entirely on the three proponents of the institutional investor value chain without diluting its attention by including governmental agencies, other non-state organizations, or corporations. Furthermore, the UN PRI not 
only provides an informational forum and support to institutional investors but also promotes directed action.

Given these commanding characteristics, the UN PRI has been successful in defining both the practice of, and the actors of importance in, responsible investment. In effect, the UN PRI should be credited with introducing and legitimizing the responsible investment ideology within mainstream finance. As discussed above this was achieved by attracting an impressive number of large institutional investors to become member signatories.

Interestingly, the characteristic of the UN PRI which attracted signatories in the first place, its lack of explicitness, is precisely what is preventing the organization, under its current culture and structure, from living up to its potential to be a significant agent of change in international environmental governance.

Without explicitly developing the goals of the UN PRI and those actions expected from its signatories, the UN PRI has attracted numerous members drawing from various motivational drivers, some of which are not conducive to internal collaboration and uniformity of action. Furthermore, aggregating institutional investors has allowed the organization to harness unparalleled market authority but it has also introduced a complex taxonomy of concerned external audiences. As the signatory base is composed of both public and private institutional investors, the UN PRI has become of concern not only for financial audiences but also public and political audiences. Ultimately, the organization's degree of legitimacy will be determined by the culmination of the perceived legitimacy originating from each of these categories of external audience. The heterogeneity, both within and between, these broad categories of external audiences should not be underestimated.

In light of such a challenging governance structure, the organization appears to be inclined to avoid explicitness in order to allow implicit understandings to produce a subtle veneer of consent and collaboration across the signatory base. As actions become increasingly prescriptive, as they must in order to ensure long term pragmatic legitimacy, differences among the signatory base are likely to emerge. As this occurs, the signatory base will be clearly divided into a core group and a peripheral group of members. Without a significant investment in mechanisms of enforcement, transparency, and accountability, the peripheral group will continue to free-ride on the core group thereby eroding the aggregate market authority of the organization over time.

The presence of a free-riding peripheral group of signatories which is significantly larger than the core group of signatories prevents the concerted market action that would be expected from such an international organization from ever materializing. In effect, the UN PRI's high degree of signatory interest in making a public commitment to responsible investment followed by a low degree of implementation presents the reality that the UN PRI is less an agent of change and more a blue-washing campaign - the organization is being used as a shroud of legitimacy by financial market participants interested in deflecting social criticism and/or gaining a competitive advantage by adopting a more 'responsible' image.

Yet, the fault does not lie entirely on the market participants as the executive directors have much to gain from the UN PRI's lack of transparency. Until the organization is critically addressed by a threshold of external audience members and widely accepted as a blue-washing campaign, which will not be long barring significant reforms to the organization's form and function, the executive directors are given a voice which is perceived to be supported by $\$ 15$ trillion USD of globally invested capital. There is a clear tension here as additional signatories will provide additional market authority to the organization and its 
directors, yet in order to attract additional signatories the organization may be forced to further decrease its already low degrees of transparency, accountability, and enforcement, which will in turn increase the risk of signatory inaction and thereby of the UN PRI being recognized as a blue-washing campaign.

Supporters of UN-associated programs have argued that external audiences should not accuse such organizations of blue-washing as the shift in discourse which they are attempting to achieve is more important than their actual implemented actions (Bigge 2004). As the UN PRI can be credited with having already legitimized the responsible investment discourse this argument no longer stands.

\section{Conclusion}

In this article I have addressed the growing interest in the establishment of effective international environmental regimes. International environmental regimes are yet another setting of international governance in which both private and public actors manoeuvre in attempts to protect their best interests while seeking an international compromise position. Accepting that many former and current attempts at establishing such international regimes have been marred in uncertainty, political impasses, significant free-riding, and general collective action problems (Young 1990), certain key actors are attempting to create an international environmental regime embedded within international financial regimes which are, arguably, more stable and better understood. These attempts are currently lead by the UN PRI.

The UN PRI is a non-state organization which aggregates institutional investor value chains, which are some of the more powerful market-based actors in contemporary financial capitalism, and is attempting to define and implement a new international financial standard known as responsible investment. The responsible investment ideology holds that long-term financial value is positively correlated with good corporate performance along environmental, social, and governance (ESG) metrics. Therefore institutional investors should seek investment possibilities which have strong ESG performance and/or engage with poorer performing assets to promote and facilitate improvement. Institutional investors are perhaps the only actors with sufficient resources, international reach, and political influence to effectively overcome the traditional obstacles inherent in international environmental governance. The perspective that long-term financial value is dependent on economic growth with low environmental impact highlights how the responsible investment ideology creates an international environmental regime within an already developed international financial regime.

Accepting that non-state organizations have developed as significant actors in international governance (e.g. Charnovitz 1996; Falkner 2003), I have drawn on previous literature to highlight three principal areas of concern in the development of the responsible investment regime. First, a non-state organization cannot resort to claims of sovereignty to establish rule-making authority but must do so by gaining legitimacy as dependent on how the organization is perceived by concerned external audiences (Suchman 1995). Second, and related, most international organizations benefit from a high degree of uncritical optimism and ultimately stray from their stated efficiency goals and wield power autonomously (Barnett and Finnemore 1999). Third, standards are a central mechanism in international governance even though the democratic establishment of many standards is questionable (Kerwer 2005).

The UN PRI has gained much legitimacy by successfully aggregating signatories with a combined market presence of over $\$ 15$ trillion USD. It has done so by providing implicit understandings of responsible investment, no mechanisms of enforcement, and a very limited degree of transparency. The majority of 
signatories have taken advantage of these characteristics to wrap themselves in an UN-sponsored shroud of legitimacy thereby deflecting social and political criticisms that they are not sufficiently responsible within an international political economy. The division of the signatory base between a highly engaged core group and a free-riding peripheral group further impacts the governance of the organization as the board of directors is not reflective of the geographical or financial distribution of the signatories. The UN PRI benefits greatly from these characteristics as the lack of transparency and accountability allows the directors to promote their agenda with the appearance that it is support by \$15 trillion USD of globally invested capital. In essence, the UN PRI's current structure and culture lead it to be perceived as an autonomous organization which is attempting to establish an international standard with no promise of representative democracy and has gained sufficient legitimacy to do so simply because it has not, until now, been critically addressed.

Although the continuing role of the UN PRI in developing an international responsible investment regime is debatable the responsible investment ideology itself holds great promise for addressing contemporary environmental change in a world driven by global finance. The further development and implementation of mainstream responsible investment practices will require that additional public and private actors become engaged. These actors can either collaborate with the UN PRI in identifying and rectifying its weaknesses which are currently enfeebling the mainstream adoption of responsible investment practices or they can side-step the UN PRI in an attempt to design a more effective international regime. Regardless, public agencies have a clear role to play in establishing the regulatory foundations for the mainstream adoption of responsible investment practices. In some cases, new regulations may not be necessary as all that is lacking is sufficient political will to implement current statutes to their full potential, as in the case of the USA's SEC in regard to corporate social disclosure (Williams 1999). Conjunctively, private actors have a clear role to play in establishing the social, competitive, and ethical landscapes from which institutional investors draw their motivations for change.

International environmental governance has long been recognized as a complicated process and the continued myriad of actors and non-synchronized initiatives demonstrates that a consensus approach is far from materializing (Pattberg and Stripple 2008). I have presented the case for the development of institutional investor responsible investment as an effective international environmental regime embedded within the more stable architecture of international finance. Actors which recognize the potential implications of responsible investment will undoubtedly be pushing for action before practitioners and academics have come to a consensual understanding of such practices, as is the case with the UN PRI. It is important that these organizations be critically discussed. These actors have significant roles to play in developing the responsible investment regime, however there always lies the risk that growing social legitimacy for the ideology will be appropriated by organizations desiring increased legitimacy and autonomous rule-making authority in an international political economy. 


\section{References}

Abbott, K.W. \& Snidal, D. 2001, "International 'standards' and international governance", Journal of European Public Policy, vol. 8, pp. 345-370.

Abbott, K.W. \& Snidal, D. 2000, "Hard and soft law in international governance", International Organization, vol. 54, pp. 421-456.

Aguilera, R., Williams, C., Conley, J. \& Rupp, D. 2006, "Corporate governance and social responsibility: a comparative analysis of the UK and the US ", Corporate Governance-An International Review, vol. 14, pp. 147-158.

Aliber, R. 1984, "International banking: a survey", Journal of Money, Credit and Banking, vol. 16, pp. 661695.

Amin, A. \& Cohendet, P. 1999, "Learning and adaptation in decentralised business networks", Environment and Planning D, vol. 17, pp. 87-104.

Bailey, R.G. 1983, "Delineation of ecosystem regions", Environmental Management, vol. 7, pp. 365-373.

Barnett, M.N. \& Finnemore, M. 1999, "The politics, power, and pathologies of international organizations", International Organizations, vol. 53, pp. 699-732.

Bauer, R., Braun, R. \& Clark, G.L. 2008, "The emerging market for European corporate governance: the relationship between governance and capital expenditures, 1997-2005", Journal of Economic Geography, vol. 8, pp. 441-469.

Bebchuk, L., Cohen, A. \& Ferrell, A. 2009, "What matters in corporate governance?", Review of Financial Studies, vol. 22, pp. 783-827.

Bernstein, S. \& Cashore, B. 2007, "Can non-state global governance be legitimate? An analytical framework", Regulation \& Governance, vol. 1, pp. 347-371.

Biermann, F. \& Dingwerth, K. 2004, "Global environmental change and the nation state", Global Environmental Politics, vol. 4, pp. 1-22.

Bigge, D.M. 2004, "Bring on the bluewash: a social constructivist argument against using Nike v. Kasky to attack the UN Global Compact", International Legal Perspectives, vol. 14, pp. 6-21.

Campbell, J.Y. \& Viceira, L.M. 2002, Strategic asset allocation: portfolio choice for long-term investors, Clarendon Press, Oxford.

Carter, A. 2001, The Political Theory of Global Citizenship, Routledge, London.

Cashore, B. 2002, "Legitimacy and the privatization of environmental governance: how non-state market-driven (NSMD) governance systems gain rule-making authority", Governance: An International Journal of Policy, Administration, and Institutions, vol. 15, pp. 503-529. 
Cashore, B., Auld, G. \& Newson, D. 2004, Governing through markets: forest certification and the emergence of non-state authority, Yale University Press, New Haven, CT.

Cashore, B. \& Vertinsky, I. 2000, "Policy networks and firm behaviours: governance systems and firm responses to external demands for sustainable forest management", Policy Sciences, vol. 33, pp. 130.

Center for Corporate Citizenship 2007, Handbook on Responsible Investment Across Asset Classes, Carroll School of Management, Boston College, Boston.

Charnovitz, S. 1996, "Two centuries of participation: NGOs and international governance", Michigan Journal of International Law, vol. 18, pp. 183-286.

CIA 2009, The World Fact Book. <www.cia.gov/library/publications/the-world-factbook/print/xx.html>

Clark, G.L. 2000, Pension Fund Capitalism, Oxford University Press, Oxford.

Clark, G.L. 1998, "Why convention dominates pension fund trustee investment decisionmaking", Environment and Planning A, vol. 30, pp. 997-1015.

Clark, G.L. \& Wojcik, D. 2007, The Geography of Finance, Oxford University Press, Oxford.

Clark, G.L. \& Hebb, T. 2005, "Why should they care? The role of institutional investors in the market for corporate global responsibility", Environment and Planning A, vol. 37, pp. 2015-2031.

Clarkson, M. 1995, "A stakeholder framework for analyzing and evaluating corporate social performance", Academy of Management Review, vol. 20, pp. 92-117.

Coffee, J. 1991, "Liquidity versus control: the institutional investor as corporate monitor", Columbia Law Review, vol. 91, pp. 1277-1368.

Davis, P.E. \& Steil, B. 2001, Institutional Investors, MIT Press, Cambridge, MA.

Del Guercio, D. \& Hawkins, J. 1999, "The motivation and impact of pension fund activism", Journal of Financial Economics, vol. 52, pp. 293-340.

Derwall, J., Gunster, N., Bauer, R. \& Koedjik, K. 2005, "The eco-efficiency premium puzzle", Financial Analysis Journal, vol. 61, pp. 51-63.

Doh, J. \& Guay, T. 2006, "Corporate social responsibility, public policy, and NGO activism in Europe and the United States: an institutional-stakeholder perspective", Journal of Management Studies, vol. 43, pp. 47-73.

Falkner, R. 2003, "Private environmental governance and international relations: exploring the links", Global Environmental Politics, vol. 3, pp. 72-87. 
Finnemore, M. 1993, "International organizations as teachers of norms: the United Nations Educational, Scientific, and Cultural Organization and science policy", International Organization, vol. 47, pp. 565-597.

Fletcher, R. \& Hansen, E. 1999, "Forest certification trends in North America and Europe", New Zealand Journal of Forestry, vol. 44, pp. 4-6.

Freshfields Bruckhaus Deringer 2005, A Legal Framework for The Integration of Environmental, Social and Governance Issues into Institutional Investment, UNEP Finance Initiative. <http://www.unepfi.org/fileadmin/documents/freshfields_legal_resp_20051123.pdf>

Gillan, S.L. \& Starks, L.T. 2000, "Corporate governance proposals and shareholder activism: the role of institutional investors", Journal of Financial Economics, vol. 57, pp. 275-301.

Gjessing, O.P.K. \& Syse, H. 2007, "Norwegian petroleum wealth and universal ownership", Corporate Governance-An International Review, vol. 15, pp. 427-437.

Glassman, J. 1999, "State power beyond the 'territorial trap': the internationalization of the state", Political Geography, vol. 18, pp. 669-696.

Gompers, P., Ishii, J. \& Metric, A. 2003, "Corporate governance and equity prices", Quarterly Journal of Economics, vol. 118, pp. 107-155.

Haigh, M. \& Hazelton, J. 2004, "Financial markets: a tool for social responsibility?", Journal of Business Ethics, vol. 52, pp. 59-71.

Hall, R.B. \& Biersteker, T.J. 2002, The Emergence of Private Authority in Global Governance, Cambridge University Press, Cambridge.

Hawley, J. \& Williams, A. 2005, "Shifting ground: emerging global corporate-governance standards and the rise of fiduciary capitalism", Environment and Planning A, vol. 37, pp. 1995-2013.

Hawley, J. \& Williams, A. 2000, The Rise of Fiduciary Capitalism: How Institutional Investors Can Make Corporate America More Democratic, University of Pennsylvania Press, Philadelphia, PA.

Hebb, T. 2008, No Small Change: Pension Funds and Corporate Engagement, Cornell University Press, New York.

Hebb, T. 2006, "The economic inefficiency of secrecy: pension fund investors' corporate transparency concerns", Journal of Business Ethics, vol. 63, pp. 385-405.

Hebb, T. \& Wojcik, D. 2005, "The institutional investment value chain: the CalPERS emerging markets strategy", Environment and Planning A, vol. 37, pp. 1955-1974.

Hummels, H. \& Timmel, D. 2004, "Investors in need of social, ethical, and environmental information", Journal of Business Ethics, vol. 52, pp. 73-84. 
IFSL 2008, Pension Markets 2008. <www.ifsl.org.uk/research>

Impavido, G. 2002, "On the governance of public pension fund management", World Bank Policy Research Working Paper No. 2878. <www.ssrn.com/abstract=636241>

IPCC 2007, Climate Change 2007: Synthesis Report, Intergovernmental Panel on Climate Change. <www.ipcc.ch/ipccreports/ar4-syr.htm>

Jacoby, S.M. 2007, "Convergence by design: the case of CalPERS in Japan", American Journal of Comparative Law, vol. 55, pp. 239-294.

Jordan, C. \& Majnoni, G. 2002, "Financial regulatory harmonization and the globalization of finance" in Globalization and national financial systems, eds. J.A. Hanson, P. Honohan \& G. Majnoni, International Bank for Reconstruction and Development/World Bank, Washington, D.C. $<$ http://ssrn.com/abstract=343260>

Kacperczyk, M. \& Seru, A. 2007, "Fund managers use of public information: new evidence on managerial skills", The Journal of Finance, vol. 62, pp. 485-528.

Kerwer, D. 2005, "Rules that many use: standards and global regulation", Governance: An International Journal of Policy, Administration, and Institutions, vol. 18, pp. 611-632.

Kindleberger, C.P. 1988, The International Economic Order: Essays on Financial Crisis and International Public Goods, MIT Press, Cambridge, MA.

Klassen, R.D. \& McLaughlin, C.P. 1996, "The impact of environmental management on firm performance", Management Science, vol. 42, pp. 1199-1214.

Markowitz, H. 1952, "Portfolio selection", Journal of Finance, vol. 7, pp. 77-91.

Meidinger, E. 1997, "Look who's making the rules: international environmental standard setting by nongovernmental organizations", Human Ecology Review, vol. 4, pp. 52-54.

Mercer 2009, IGF-Gaining Ground: Integrating ESG Factors Into Investment Processes in Emerging Markets. <www.mercer.com/ri>

Murdoch, J.C. \& Sandler, T. 1997, "The voluntary provision of a pure public good: the case of reduced CFC emissions and the Montreal Protocol", Journal of Public Economics, vol. 63, pp.331-349

Nelson, J.M. 2006, "The 'CalPERS effect' revisited again", Journal of Corporate Finance, vol. 12, pp. 187213.

Nordhaus, W.D. 1994, Managing the Global Commons, MIT Press, Cambridge, MA.

Offe, C. 1975, "The theory of the capitalist state and the problem of policy formation" in Stress and Contradiction in Modern Capitalism, eds. L.N. Lindberg, R. Alford, C. Crouch \& C. Offe, Heath, Lexington. 
Ohmae, K. 1995, The End of The Nation State: The Rise of Regional Economies, Harper Collins, London.

Orlitzky, M., Schmidt, F.L. \& Rynes, S.L. 2003, "Corporate social and financial performance: A metaanalysis", Organization Studies, vol. 24, pp. 403-441.

Pattberg, P. \& Stripple, J. 2008, "Beyond the public and private divide: remapping transnational climate governance in the 21st century", International Environmental Agreements: Politics, Law and Economics, vol. 8, pp. 367-388.

Rose, P. 2007, "The corporate governance industry", The Journal of Corporation Law, vol. 32, pp. 887926.

Rosenau, J.N. 1997, Along the Domestic-Foreign Frontier: Exploring Governance in a Turbulent World, Cambridge University Press, Cambridge.

Ryan, L.V. \& Schneider, M. 2002, "The antecedents of institutional investor activism", Academy of Management Review, vol. 27, pp. 554-573.

Scott, W.R. 2001, Institutions and Organizations, Second Edition, Sage Publications, Thousand Oaks.

Shameek, K. \& Cohen, M.A. 2001, "Does the market value environmental performance?", Review of Economics \& Statistics, vol. 83, pp. 281-289.

Shonfield, A. 1965, Modern Capitalism: The Changing Balance of Public and Private Power, Oxford University Press, London.

Sorsa, V.P. 2008, "How to explain socially responsible corporate actions institutionally: theoretical and methodological critique", Electronic Journal of Business Ethics and Organization Studies, vol. 13, pp. $32-41$.

Sparkes, R. 2002, Socially Responsible Investment, John Wiley \& Sons, West Sussex.

Sparkes, R. 1995, The Ethical Investor, Harper Collins, London.

Steelman, T. \& Rivera, J.E. 2006, "Voluntary environmental programs in the United States: whose interests are served?", Organization \& Environment, vol. 19, pp. 505-526.

Stern, N.H. 2007, The Economics of Climate Change: The Stern Review, Cambridge University Press, Cambridge.

Strickland, D., Wiles, K. \& Zenner, M. 1996, "A requiem for the USA: is small shareholder monitoring effective?", Journal of Financial Economics, vol. 40, pp. 319-338.

Stulz, R. 2005, "The limits of financial globalization", The Journal of Finance, vol. 60, pp. 1595-1637.

Suchman, M.C. 1995, "Managing legitimacy: strategic and institutional approaches", Academy of Management Review, vol. 20, pp. 571-610. 
Tharoor, S. 2003, "Why America still needs the United Nations", Foreign Affairs, vol. 82, pp. 67-80.

UN PRI 2008, PRI Report on Progress 2008.

<http://www.unpri.org/files/2008PRI_Report_on_Progress.pdf>

Valor, C. 2005, "Corporate social responsibility and corporate citizenship: towards corporate accountability", Business \& Society Review, vol. 110, pp. 191-212.

Wahal, S. 1996, "Pension fund activism and firm performance", Journal of Financial and Quantitative Analysis, vol. 31, pp. 1-23.

Wapner, P. 1995, "Politics beyond the state: environmental activism and world civic politics", World Politics, vol. 47, pp. 311-337.

Wenger, E. 1999, Communities of Practice: Learning, Meaning, and Identity, Cambridge University Press, UK.

Wettestad, J. 2001, "Designing effective environmental regimes: the conditional keys", Global Governance, vol. 7, pp. 317-342.

Williams, C.A. 1999, "The Securities and Exchange Commission and corporate social transparency", Harvard Law Review, vol. 112, pp. 1197-1307.

Yeung, H.W.C. 1998, "Capital, state and space: contesting the borderless world", Transactions of the Institute of British Geographers, vol. 23, pp. 291-309.

Young, O.R. 2002, "Evaluating the success of international environmental regimes: where are we now?", Global Environmental Change, vol. 12, pp. 73-77.

Young, O.R. 1990, "Global environmental change and international governance", Millenium: Journal of International Studies, vol. 19, pp. 337-346. 